\title{
Lifecycles for E-Government in Latin America
}

\author{
Juan Pablo Giraldo Rendón \\ Candidato a Doctor en Ingeniería \\ Informática Profesor - Facultad de \\ Ciencias e Ingeniería Universidad \\ de Manizales: Colombia
}

\author{
Luis Joyanes Aguilar \\ Doctor en Ingeniería Informática \\ Doctor en Sociología \\ Profesor de Lenguajes y Sistemas \\ Informáticos \\ Universidad Pontificia de \\ Salamanca \\ Profesor Visitante e Investigador \\ Asociado Internacional de la \\ Universidad de Medellin(Colombia) \\ Profesor Visitante e Investigador \\ Internacional de la Universidad \\ Católica de Santiago de Guayaquil
}

\author{
Lillyana Giraldo Marin \\ Doctora en Ingeniería Informática \\ Profesor Investigador- Facultad de \\ Ingenierías \\ Universidad de Medellín, Colombia
}

(Ecuador)

\begin{abstract}
The projects for e-government in Latin America are mediated by government policies that were decided jointly between countries. What is not explicit is the need for institutions to have strategies to support these projects. In the text lifecycles contributing to this construction in Latin American government entities to arise
\end{abstract}

\section{Keywords}

Lifecycles, e-goverment.

\section{INTRODUCTION}

E-Government is a necessity. Today is required connectivity and communications between governments. It's very nice idea, the ICT (Modern information and communication technologies have created a "global village," in which people can communicate with others across the world as if they were living next door.) technologies transform this possibility in a reality. But it's necessary to work together and talk the same "language". The informatics language requires preliminary steps that are performed within the state institutions.

All steps requires work efficiently with data and information using life cycles, this provide structured and details methods and methodologies, Oracle define: Information Lifecycle Management (ILM) is the practice of applying policies for the effective management of information throughout its useful life. [1]. All institutions have policies to manipulate data and information, but exists other life cycles inside the institutions, this work with the regular people and work to create a sucessfull e-government. .

\section{E-GOVERMENT IN LATIN AMERICA}

With the common acceptation of the white book to interoperability to e-government (Libro blanco para interoperabilidad para gobierno en linea) [2], start the path to create projects and programs to implant the ideas inside the book. For example:

- Colombia: GEL project. (Gobierno En Línea)

- Costa Rica. Gobierno digital

- Ecuador. Plan nacional de gobierno electrónico.

- Chile:Proyecto de la unidad de modernización y gobierno digital.
- Uruguay: Agencia AGESIC - Gobierno electrónico.

- Argentina: Plan nacional y sectorial de Gobierno electrónico.

- Mexico: Proyectos comisión de gobierno electrónico.

- Brasil: Proyectos secretaría de logística y tecnología de la información.

All projects have common requirements, the principals are:

- Analysis for internal operations

- Development Systems information and Mobile apps

- Create software interface

- Users characterization

- Management results

- Evaluation of citizens

- Management of Web channels

- Documentation and online procedures for citizens

- Management projects

- Technological government

- Strategic orientation -

To deal with the characterization of the expected results is necessary that the entity has methods, strategies, resources, everything a toolbox that would respond and move forward successfully in the plans, programs and projects. The big components are: Internal operations, information systems, relationship with the citizens and technologies management.

In this moment the concept of lifecycle is relevant, it's the principal tool to develop components and projects.

\section{LIFECYCLES}

\subsection{Formality and internal process}

A chain step is generated when an entity performs a process requested by a citizen or entrepreneur, management demand access to another entity in order to needs to requirements for the implementation. [3]There is need to analyze the agencies involved and perform a simple lifting of data and information in the form of requirements so that the various options considered and stakeholders who are part of the various stages 
of the chain. To fig 1, present a lifecycle to develop this actions.

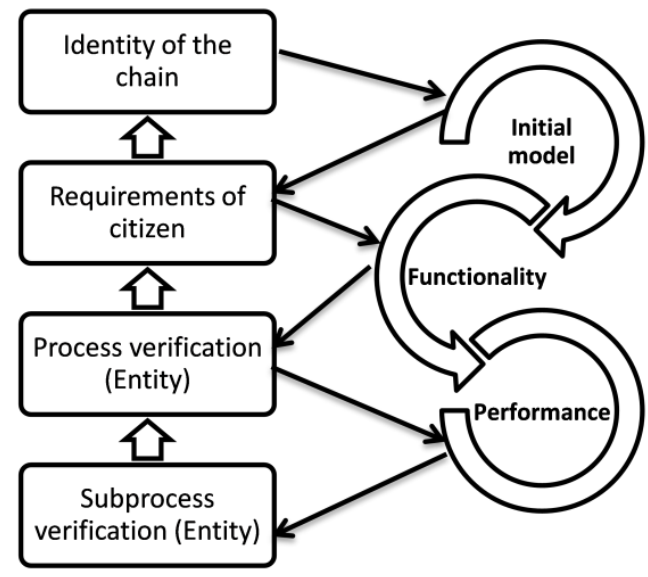

Fig 1: Lifecycle to internal process

The internal process inside the government organizations require differents points of view, each one thinking in structure, operations and data, this issue need a representation and methods to extract the information. The fig 2 present a method to document step by step the internal process, this one is complementary with the general lifecycle (fig 1).

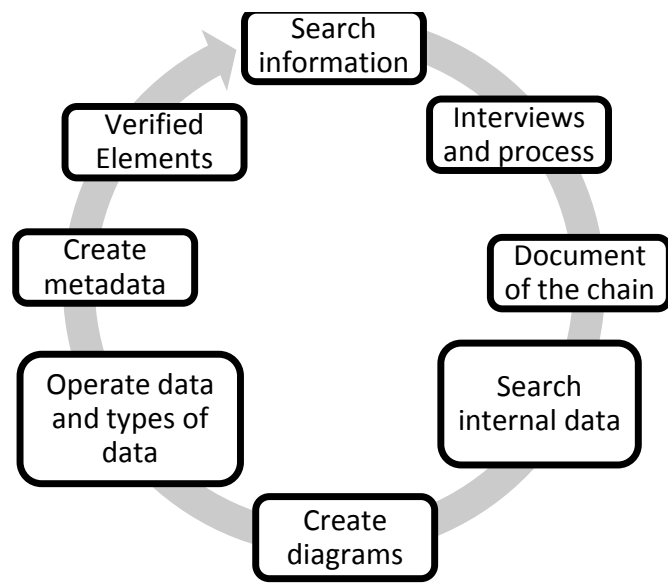

Fig 2: Detail analysis to internal process

\subsection{Technological management}

Is the set of policies, responsibilities and actions of technological administration leading to the company to a state of interaction with all instances, fully interconnected with all social groups, working together in projective themes and objectives, finding solutions to general problems in the implementation of policies and programs in a consistent, ethical and democratic way. [4]

The technology management within government institutions is projected as a strategy for adjusting work plans, vision, policies, controls, corrections and the coordination where people are able to participate in all the technological areas, according to the government rules.

Table 1. Components to technological management

\begin{tabular}{|c|c|}
\hline $\begin{array}{c}\text { Component / } \\
\text { Subcomponent }\end{array}$ & Description \\
\hline Planning and organize. Gives the orientation to \\
Acquire, implement, deliver and support tech \\
\hline
\end{tabular}

\begin{tabular}{|c|c|}
\hline \multicolumn{2}{|l|}{ solutions. } \\
\hline Evaluate & $\begin{array}{l}\text { Define technological } \\
\text { competitiveness and internal } \\
\text { potential to innovate and } \\
\text { evaluate financial impacts. }\end{array}$ \\
\hline \multicolumn{2}{|c|}{$\begin{array}{l}\text { Monitor and evaluate. Monitor all process and } \\
\text { verified adequate operations. }\end{array}$} \\
\hline $\begin{array}{l}\text { Observation } \\
\text { process }\end{array}$ & $\begin{array}{l}\text { Study evolution of new } \\
\text { technologies, evaluate the } \\
\text { impact of this technologies in } \\
\text { the different areas. }\end{array}$ \\
\hline Obsolescence & $\begin{array}{l}\text { Is a transversal action in this } \\
\text { lifecycle, search and } \\
\text { development new options for } \\
\text { the technological innovation. }\end{array}$ \\
\hline \multicolumn{2}{|c|}{$\begin{array}{l}\text { Deliver and support. Gives solutions to makes } \\
\text { them useful for the end users. }\end{array}$} \\
\hline $\begin{array}{l}\text { Assimilation } \\
\text { process }\end{array}$ & $\begin{array}{l}\text { Is the implementation and } \\
\text { tuning for the technologies, } \\
\text { using strategies like: } \\
\text { Stakeholders training. } \\
\text { Creation of technologies } \\
\text { documents. Creation of new } \\
\text { applications. Efficient } \\
\text { management of resources. }\end{array}$ \\
\hline \multicolumn{2}{|c|}{$\begin{array}{l}\text { Acquirement and implementation. } \\
\text { Presentation of solutions according to } \\
\text { requirements and transform in services. }\end{array}$} \\
\hline $\begin{array}{c}\text { Tech } \\
\text { Enrichment }\end{array}$ & $\begin{array}{l}\text { Create options to transform } \\
\text { between the different } \\
\text { conditions. It's important to } \\
\text { consider: Search and } \\
\text { development; Prioritize } \\
\text { emerging technologies; } \\
\text { strategy acquisition and } \\
\text { define new projects. [5] }\end{array}$ \\
\hline Inventory & $\begin{array}{l}\text { To gather available } \\
\text { technologies for the entity, } \\
\text { and at the same time identify } \\
\text { key technologies. }\end{array}$ \\
\hline \multicolumn{2}{|c|}{$\begin{array}{l}\text { Protection. Create policies to operate } \\
\text { technologies and including conditions protocols } \\
\text { for final results. }\end{array}$} \\
\hline
\end{tabular}

The lifecycle is presented on the Fig 4 .

These components required an operation structure, the first step is general with policies, the final step is particular with actions. (Fig 3)

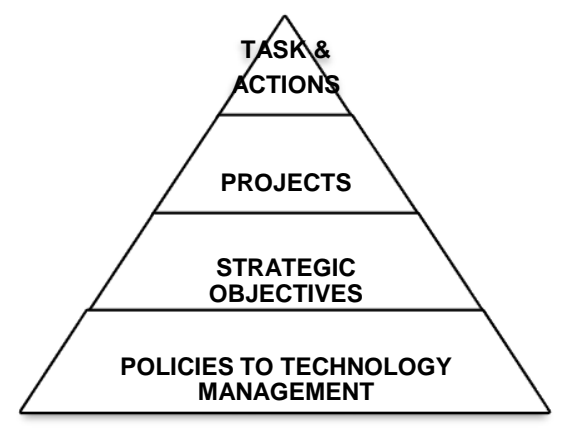

Fig 3: Operations structure to tech management 


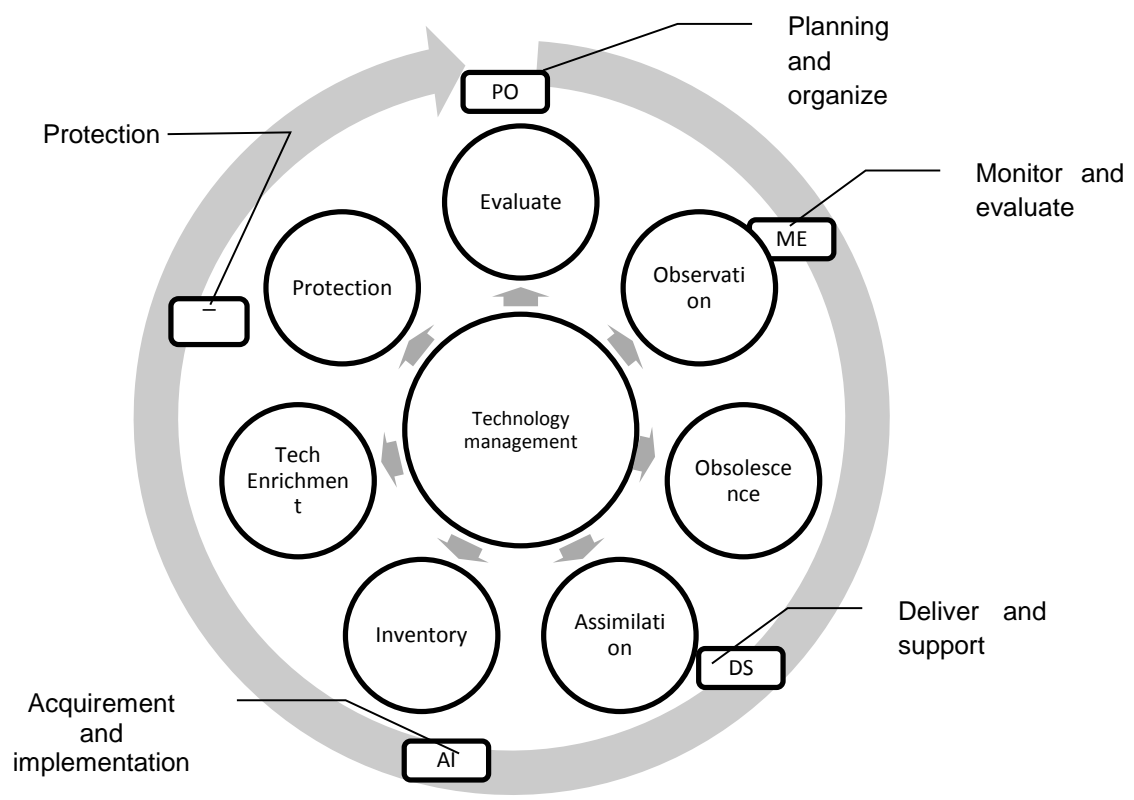

Fig 4: Lifecycle to technology management

\subsection{System information}

In the past and now days the software development requires documents, diagrams. For 40 years analyst, designers and programmers have to be creating lifecycles and options to development software. All options have a portion of reality and application.

For the government and its institutions is necessary creation of details documents about all process, it's the reason to use a STEPHENS ideas. [6]

Requirements. One of the first steps in a software project is figuring out the requirements. You need to find out what the customers want and what the customers need. You can turn them into requirements documents. Those documents tell the customers what they will be getting, and they tell the project members what they will be building.

High level design. The high-level design includes such things as decisions about what platform to use, what data design to use, and interfaces with other systems. You should make sure that the high-level design covers every aspect of the requirements. It should specify what the pieces do and how they should interact, but it should include as few details as possible about how the pieces do their jobs

Low level design. The low-level design includes information about how that piece of the project should work. The design doesn't need to give every last nitpicky detail necessary to implement the project's major pieces, but they should give enough guidance to the developers who will implement those pieces.

Development. It's time for the programmers to get to work. The programmers continue refining the low-level designs until they know how to implement those designs in code. As the programmers write the code, they test it to make sure it doesn't contain any bugs.

Testing. Effectively testing your own code is extremely hard. If you knew there was a bug in the code, you would have fi xed it before you wrote it. That idea often leads programmers to assume their code is correct. Even if a particular piece of code is thoroughly tested and contains no (or few) bugs, there's no guarantee that it will work properly with the other parts of the system. Edsger W. Dijkstra said, "Testing shows the presence, not the absence of bugs".

Deploy. Ideally, you roll out your software, the users are overjoyed, and everyone lives happily ever after. Often, however, things don't go so smoothly. Deployment can be difficult, time consuming, and expensive.

Support. Bugs that were completely hidden from testers appear the instant users touch the application. If your application is successful, users will use it a lot, and they'll be even more likely to find bugs. Every software developer wants to have a customers that like an application so much, they're clamoring for more.

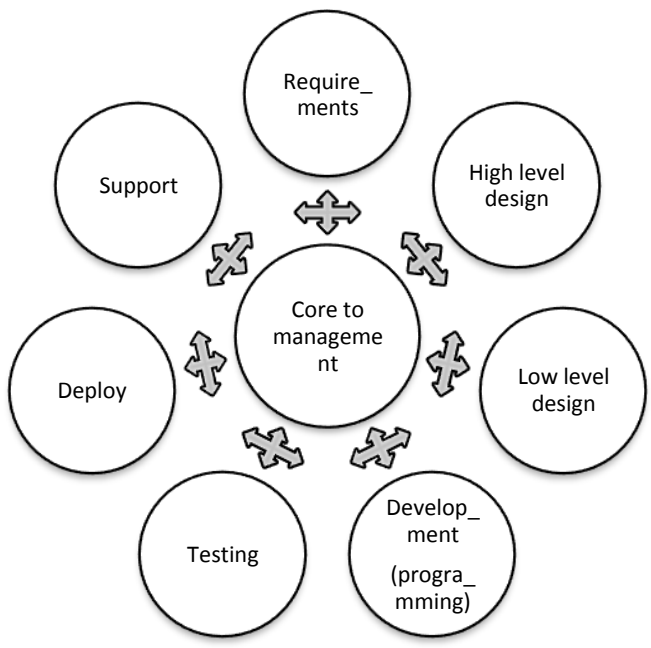

Fig 5: Lifecycle to systems information 
This global ideas present to IT leaders and experts, conditions to create and document software constructions.

\subsection{Relationship with the citizens}

The principal idea is to analyze the characteristics about the citizens, and offer better services thinking in segmented social groups. The principal information is: Geographic, demographic and behavior.

Geographic: location, population, population density and weather.

Demographic: Age, gender, family group, occupation, education, income, language, ethnicity and vulnerability conditions.

Behavior: Frequency of use services, evaluation of services, needs of interaction and satisfaction.

This set of variables creates a profile about citizens and create opportunities to new ways of communication and interaction.

The actions to acquire the information require global actions, to validate data and create strategies to analyze and design new ways to feedback between citizens, corporations and government.

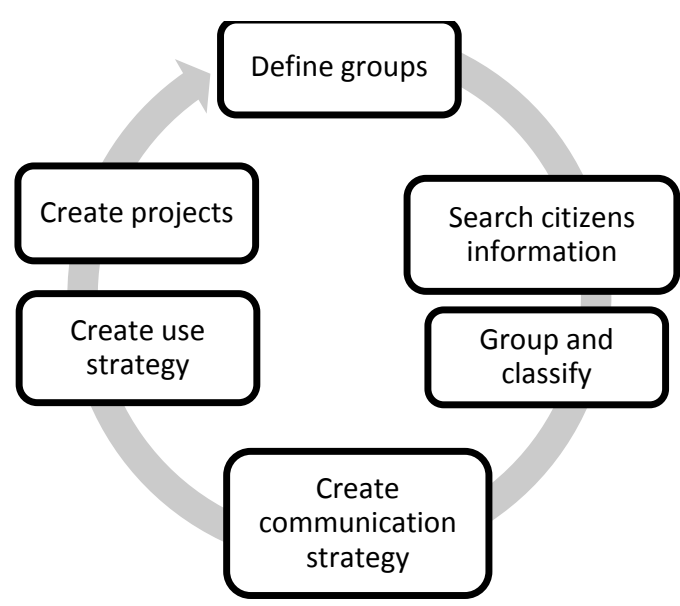

Fig 6: Lifecycle to citizens information

Each case present detail data and information, this results needs quality in the process, to ensure the success.

\section{CONCLUSIONS}

The life cycles are support tools of quality in the process of government agencies. In general they operate individually. For the e-government the power is to operate in conjunction with the stakeholders. These ideas are a beginning to develop e-government in Latin America. Each country have alternatives to apply and develop a government online, and have general and particular components, for example sequence of administrative steps, citizens characterizations have a particular definition, contrary to software and metadata. The prospective in research to general components are:

- Create software design patrons to e-government.

- Define metadata to create and strengthen relationships between governments.

\section{REFERENCES}

[1] ORACLE, «Management storage,» Mayo 2015. [En línea].

Available: http://www.oracle.com/us/products/database/database11g-managing-storage-wp-354099.pdf. [Último acceso: 20 Septiembre 2015].

[2] CEPAL, Libro blanco de la interoperabilidad de gobierno electrónico para américa latina y el caribe. Naciones Unidas, CEPAL, 2007.

[3] MINTIC - Ministerio de Tecnología de la Información y la Comunicación - Colombia, «Guía de cadenas de trámite,» MINTIC, Bogotá, 2009.

[4] J. P. GIRALDO RENDON, «Metamodelo para implantación del proyecto gobierno en línea de la República de Colombia con enfoque en la nube, macrodatos, y datos abiertos,» Tesis Doctoral, Manizales Caldas - Colombia, 2015.

[5] H. A. PAVÓN Julian, Gestión e innovación . Un enfoque estratégico, Madrid: Piramide, 1997.

[6] STEPHENS. Rod, Begining Software Engineering, Indianapolis. USA: John Wiley \& Sons, 2015.

[7] CALDERON César, \& LORENZO Sebastián. Open Government - Gobierno Abierto. Alcala la Real: Algón Editores. 2010

[8] EUROPEAN COMISSION.. European interoperability framework for pan-european eGovernment services. Belgium: European communities. 2004

[9] HULL, Elizabeth. JACKSON, Ken. DICK, Jeremy Requirements Engineering. New York. Springer -Verlag. 2011.

[10] TAPIAS Heberto. Gestión Tecnológica y Desarrollo Tecnológico. Ingeniería - Universidad de Antioquia. 2000 